Discussion Paper No. 09-026

Common Corporate Tax Base (CCTB) and Effective Tax Burdens in the EU Member States

Andreas Oestreicher, Timo Reister, and Christoph Spengel

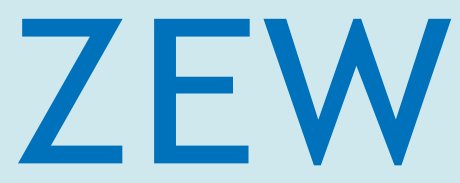

Zentrum für Europäische Wirtschaftsforschung $\mathrm{GmbH}$

Centre for European

Economic Research 
Discussion Paper No. 09-026

\title{
Common Corporate Tax Base (CCTB) and Effective Tax Burdens in the EU Member States
}

\author{
Andreas Oestreicher, Timo Reister, \\ and Christoph Spengel
}

Download this ZEW Discussion Paper from our ftp server:

ftp://ftp.zew.de/pub/zew-docs/dp/dp09026.pdf

Die Discussion Papers dienen einer möglichst schnellen Verbreitung von neueren Forschungsarbeiten des ZEW. Die Beiträge liegen in alleiniger Verantwortung der Autoren und stellen nicht notwendigerweise die Meinung des ZEW dar.

Discussion Papers are intended to make results of ZEW research promptly available to other economists in order to encourage discussion and suggestions for revisions. The authors are solely responsible for the contents which do not necessarily represent the opinion of the ZEW. 


\section{Non-technical Summary}

EU companies face many tax obstacles in their EU-wide cross-border activities. These include the high compliance costs, the lack of cross-border loss-offset and the risk of double taxation as a result of conflicting rights between member states. To tackle these problems, the European Commission envisages putting forward a proposal for a tax reform that would allow improving the efficiency and simplicity of the corporate income tax systems in the EU. One policy option is the introduction of a Common Corporate Tax Base (CCTB) that would replace the current 27 tax codes for the computation of taxable income across member states by a single and common set of tax rules.

The idea of this paper is to provide an analysis of the consequences which an adoption of a CCTB would have on effective tax burdens of EU companies located in each of the 27 member states, using the model of the European Tax Analyzer. The tax accounting rules considered are based on the proposals of the working group concerned with the Common Consolidated Corporate Tax Base and comprise concrete taxation rules for eight different elements of the tax base: depreciation rules, valuation of inventories, determination of production costs, treatment of $R \& D$ costs, provisions for future pension payments, provisions for legal obligations, avoidance of double taxation of dividend income and loss relief.

Quantitative analyses executed for EU-27 average large and small and medium-sized companies show remarkable dispersions of effective tax burdens at corporate level across member states. Furthermore, the results indicate that the proposed CCTB has a considerable impact on effective tax burdens. Primarily caused by restrictive depreciation rules the concept would generally broaden the tax bases within the EU if all member states uniformly adopt a CCTB. Consequently, behind the background of revenue neutrality of an introduction of a CCTB the results suggest that the implementation of the analyzed common set of tax rules could be accompanied by a reduction of nominal tax rates within in EU member states. 


\section{Zusammenfassung}

EU-Unternehmen sehen sich in ihren grenzüberschreitenden Tätigkeiten innerhalb des Gemeinschaftsgebietes zahlreichen steuerlichen Hindernissen ausgesetzt. Diese beinhalten hohe steuerliche Befolgungskosten, das Fehlen von grenzüberschreitenden Verlustausgleichsmöglichkeiten sowie das Risiko von Doppelbesteuerungen infolge von kollidierenden Besteuerungsrechten zwischen den Mitgliedstaaten. Um diesen Problemen entgegenzutreten, forciert die EU-Kommission eine Reform der Unternehmensbesteuerung, die eine Verbesserung der Effizienz und eine Reduktion des Komplexitätsgrades der Unternehmenssteuersysteme in der EU gewährleisten soll. Eine Reformoption besteht in diesem Zusammenhang in der Einführung einer gemeinsamen Körperschaftsteuer-Bemessungsgrundlage, welche die derzeit existierenden 27 nationalen Regelungswerke zur Ermittlung des steuerlichen Einkommens durch einheitliche steuerliche Vorschriften ersetzen soll.

Ziel dieses Papiers ist es, die Konsequenzen der Einführung einer gemeinsamen Körperschaftsteuer-Bemessungsgrundlage auf die effektive Steuerbelastung von EU-Unternehmen unter Verwendung des Computersimulationsmodels European Tax Analyzer zu analysieren. In die Berechnungen werden dabei die Steuersysteme sämtlicher EU-27 Mitgliedstaaten einbezogen. Hinsichtlich der untersuchten steuerlichen Einzelvorschriften wird auf die Vorschläge der von der EU-Kommission eingesetzten Arbeitsgruppe "Gemeinsame konsolidierte Körperschaftsteuer-Bemessungsgrundlage" zurückgegriffen. Im Einzelnen decken die Untersuchungen acht Elemente der körperschaftsteuerlichen Bemessungsgrundlage ab: Abschreibungsregelungen, Vorschriften zur Vorratsbewertung, die Definition steuerlicher Herstellungskosten, die steuerliche Behandlung von F\&E-Aufwendungen, Regelungen bezüglich der Bildung von Pensions- und Gewährleistungsrückstellungen, die Systematik zur Vermeidung von Doppelbesteuerungen von Dividendeneinkünften sowie Vorschriften zur steuerlichen Verlustberücksichtigung.

Die für große sowie kleine/mittelgroße EU-27-Durchschnittsunternehmen durchgeführten quantitativen Analysen zeigen, dass die berechneten effektiven Steuerbelastungen auf Ebene der Kapitalgesellschaften über die Mitgliedstaaten hinweg starken Streuungen unterliegen. Darüber hinaus geben die Ergebnisse Aufschluss darüber, dass die vorgeschlagene gemeinsame Körperschaftsteuer-Bemessungsgrundlage die Höhe der gemessenen Effektivsteuerbelastungen spürbar beeinflusst. In erster Linie sorgen restriktive Abschreibungsregelungen des analysierten Konzepts dafür, dass es grundsätzlich zu Verbreiterungen der Bemessungsgrund- 
lagen innerhalb der EU kommt, wenn alle Mitgliedstaaten das vorgeschlagene Reformkonzept simultan umsetzen. Vor dem Hintergrund des Kriteriums der Aufkommensneutralität könnte die Umsetzung einer gemeinsamen Körperschaftsteuer-Bemessungsgrundlage somit Raum für Senkungen der nominellen Steuersätze in den EU-Mitgliedstaaten schaffen. 


\title{
Common Corporate Tax Base (CCTB) and Effective Tax Burdens in the EU Member States ${ }^{1}$
}

\author{
Andreas Oestreicher*, Timo Reister**, Christoph Spengel***
}

April 2009

\begin{abstract}
The article assesses the impact of a Common Corporate Tax Base (CCTB) as promoted by the European Commission and the related Working Groups on the effective tax burdens of companies in all $27 \mathrm{EU}$ member states. The results shall help to evaluate the economic consequences of introducing a harmonized set of tax accounting rules for EU-based companies. The proposals for a CCTB covered here include depreciation on intangibles, machinery, buildings, furniture and fixture, simplified valuation of inventories, determination of production costs for stocks, treatment of costs for R\&D as part of production costs, provisions for future pension payments, provisions for legal obligations, avoidance of double taxation regarding dividend income, and loss relief. The proposed options for a CCTB are applied for average EU-27 corporations of different size as well as for model companies belonging to different economic sectors.
\end{abstract}

Keywords: European Taxation, Tax Harmonization, Tax Accounting, Effective Tax Burdens JEL-Classification: H20, H21, H25, K34

\footnotetext{
* Andreas Oestreicher holds the chair of Business Administration and Taxation at the Georg-August University of Goettingen and is director of the Institute for Domestic and International Taxation as well as Research Associate at the Centre of European Economic Research (ZEW)

(andreas.oestreicher@uni-goettingen.de)
}

** Timo Reister is Research Fellow at the Centre of European Economic Research (ZEW) (reister@zew.de)

*** Christoph Spengel holds the chair of Business Administration and Taxation II at the University of Mannheim,and is Research Associate at the Centre of European Economic Research (ZEW)

(spengel@uni-mannheim.de)

\footnotetext{
${ }^{1}$ The authors would like to thank the European Commission for valuable input and support in project TAXUD//2007/DE/325 and Christof Ernst, Katharina Finke, Michael Grünewald and Jens Prassel for their impact in this project.
} 
EU companies face many tax obstacles in their EU-wide cross-border activities. These include the high compliance costs, the lack of cross-border loss-offset and the risk of double taxation as a result of conflicting rights between member states. To tackle these problems, the European Commission envisages putting forward a proposal for a tax reform that would allow improving the efficiency and simplicity of the corporate income tax systems in the EU.

The most comprehensive approach would be a Common Consolidated Corporate Tax Base (CCCTB) which encompasses all elements of cross-border consolidation and loss compensation. A less far reaching approach - the Common Corporate Tax Base (CCTB) - covers all other non consolidation and non loss-compensation related provisions defining the domestic tax bases of EU companies. This policy option would replace the current 27 tax codes for the computation of taxable income across member states by a single and common set of tax rules.

The aim of this paper is to provide an analysis of the consequences which an adoption of a CCTB would have on effective tax burdens of EU companies located in each of the 27 member states, using the model of the European Tax Analyzer. This model allows demonstrating to what extent tax burdens are influenced by differing tax systems, types of taxes, tax bases, and tax rates. More specifically, in the following the impact on the EU companies' effective tax burdens of moving from the prevailing corporate tax systems to alternative options for a CCTB, i.e. to an EU-wide harmonisation of selected non-consolidation and non cross-border loss-compensation related major provisions of the corporate tax base, is quantified. Since the focus is on the effective corporate tax burdens of companies, the analysis is limited to corporations (i.e. transparent entities are not taken into account) and to taxes borne at the corporate level (i.e. personal taxes of shareholders are not taken into account).

Section 2 specifies the scenario of a Common Corporate Tax Base. Section 3 introduces the methodological concept for the computation of effective company tax burdens as well as the underlain data base. In Section 4 the effective company tax burdens and their developments in the EU-27 member states are compared and analysed. Finally, section 5 concludes the discussion.

\section{Scenario of a Common Corporate Tax Base}

The tax accounting rules considered are based on the proposals of the working group concerned with the Common Consolidated Corporate Tax Base. ${ }^{2}$ Altogether, eight different elements of the tax base are taken into consideration. These elements are outlined in the following.

- Depreciation rules for intangible assets, machinery, buildings, furniture and fixture (option A): A distinction is made between long-term and short to medium term assets depending on the useful lifetime of each asset. In case of machinery as well as furniture and fixture pool depreciation is done at a rate of $20 \%$. Special rules apply to buildings (individual straight-line depreciation with a rate of $2.5 \%$ ) and intangible assets (individual straightline depreciation with a general rate of $6.67 \%$ ).

\footnotetext{
${ }^{2}$ For the latest Working Document concerning the CCCTB see Common Consolidated Corporate Tax Base Working Group (2007).
} 
- Valuation of inventories (option B): The weighted average cost method is chosen. Accordingly, items in inventory and the cost of goods which are sold in the period are valued with average costs. The average is calculated using costs of the units being in stock at that time.

- Production costs (option C): All direct costs are treated as production costs.

- Costs for R\&D as part of production costs (option D): The considered CCTB option is to include costs for development which can be allocated directly to the specific production. Research costs, in contrast, are deemed to be expensed as they are not in direct relation to production.

- Provisions for future pension payments (option E): The considered CCTB option here is to use IFRS rules for the determination of pension provisions. This implies a harmonisation of the discount rate and rules regarding the projection of future developments of pension costs (e.g. increases in labour costs).

- Provisions for legal obligations (e.g. warranty claim, option F): The considered CCTB option is to treat contributions to such provisions as tax deductible when certain requirements are met, e.g. reliable estimation is possible and the liability is tax deductible itself.

- Avoidance of double taxation of dividends (option G): The option for a CCTB is to exempt dividends from major shareholding (participation ratio $\geq 10 \%$ of shares). Exemption of dividends results in a lower tax burden compared to the credit method, if the foreign income tax is lower than the domestic tax. The assumed foreign tax rate is $30 \%$.

- Loss relief (option H): The CCTB option is an indefinite carry forward of losses without the possibility for loss carry back within a single company.

\section{Methodology and Data Base}

\subsection{Computation of effective tax burdens}

Various measures for effective tax burdens have been developed. ${ }^{3}$ Depending on the purpose of the tax burden comparison, it is possible to distinguish between the effective marginal tax burden and the effective average tax burden. The effective marginal tax burden measures the extra tax of an additional (marginal) investment project that is just worthwhile, i.e. the presumed rate of return equals the cost of capital. The effective average tax burden measures the effective tax burden of projects that earn more than the capital costs, i.e. those generating economic rents or positive net present values. This measure is of high relevance for location decisions of multinationals ${ }^{4}$ and the competitive situation of SMEs. Since this article assesses the impact of harmonized tax accounting rules on the attractiveness of member states as a place of location for companies, the effective average tax burden is the relevant measure.

The standard model for the calculation of the effective average tax burden is the approach of Devereux and Griffith. ${ }^{5}$ Another method is a model-firm approach which, in its simplest form, is a firm-specific combination of several investments and sources of finance taking into account at the same time all relevant interrelations between sales, investment, profit distribution and financing, etc. The European Tax Analyzer is such an approach.

\footnotetext{
${ }^{3}$ See Jacobs and Spengel, 2000: 334-351.

${ }^{4}$ See Devereux and Griffith, 1998: 335-367; Richter, Seitz, and Wiegard, 1996: 13-47.

${ }^{5}$ See Devereux and Griffith, 1999.
} 


\subsection{European Tax Analyzer Model}

The European Tax Analyzer was developed by the Centre for European Economic Research (ZEW) and the University of Mannheim and approved in an earlier study for the European Commission. ${ }^{6}$ It is a model-firm approach calculating and comparing effective average tax burdens for companies located in different countries. The following takes into account the tax systems of the EU-27 member states.

The effective average tax burden is derived by simulating the development of a corporation over a ten year period. It is expressed as the difference between the pre-tax and the post-tax value of the firm at the end of the simulation period (i.e. period 10). The value of the firm is represented by the equity, which includes the capital stock and the cumulative net income of each period. At the end of period ten, the tax value of assets and liabilities may differ from their fair value, depending on the tax rules which are to be applied. These unrealized profits and liabilities are added to the taxable income in period ten and are taxed accordingly. As a consequence, only the effects of different tax accounting rules on the liquidity are taken into account. Remaining loss carry forwards at the end of the simulation are dissolved liquidityrelated whereas a devaluation of 50 per cent is made if there are no restrictions for the use of loss carry forwards and a devaluation of 75 per cent if there are any restrictions.

In contrast to models which compute tax burdens solely based on pre-tax returns, ${ }^{7}$ calculations based on cash receipts and cash expenses regarding balancing investments allow for the entire computation of all tax bases at any time during the period of simulation (because all relevant income and assets have been entered into the tax base). As a consequence, the model can include complicated tax provisions such as progressive tax rates, tax credits (e.g. for foreign taxes) with upper ceilings, and loss carryovers without any difficulty.

Within this conceptual framework the calculations take an industry-specific mix of assets and liabilities as a starting point. The assets consist of real estate, office and factory buildings, plant and machinery, office equipment, intangibles (patents and royalties), financial assets, shares in other corporations (both domestic and foreign), inventories, trade debtors, cash funds, and deposits. The liabilities include long-term and short-term debt, and trade creditors. Based on this (in general existing) capital stock, the future pre-tax profits are derived on the basis of estimates for the future cash receipts and cash expenses associated with the initial capital stock.

Estimates are based on periodical assumptions for production and sales, acquisition of goods, staff expenditure (e.g. remuneration and pension costs), other receipts and expenses (e.g. expenses for R\&D), investment, distribution, and costs of financing. Goods are assumed to be either stocked or sold on the market in the same period as they are produced. Therefore, multi-period production is possible. Additional assumptions are made for material and labour with regard to production costs. It is further assumed that depreciable assets (i.e. buildings, plant and machinery, office equipment, and intangibles) are run down at the end of their expected economic life. Reinvestments in new assets are made at that point based on the historical costs of the deposited assets adjusted for inflation. The model's assumptions regarding investment make sure that the initial capital stock at least remains constant. In addition to differing rates of price increases, other macro-economic data considered are credit and debit interest rates, exchange rates for the given countries and the costs of energy and electricity.

\footnotetext{
${ }^{6}$ See Jacobs and Spengel, 2002. For detailed descriptions of the model see also Spengel, 1995; Jacobs \& Spengel, 1996; Meyer, 1996; Stetter, 2005; Gutekunst, 2005.

${ }^{7}$ See Schreiber, Spengel, and Lammersen, 2002: 2-23.
} 
In order to determine the post-tax profits the tax liabilities are derived by taking into account the tax bases according to the existing domestic rules (i.e. GAAPs) or the proposed CCTB rules and then applying the national tax rates. As such model-firms, if computer based, can easily be run under alternative sets of assumptions on key variables such as pre-tax receipts and expenses, types and age of assets, sources of finance etc., they may provide reliable results for different circumstances and even different industries.

\subsection{Tax Parameters Incorporated into the Model}

In order to calculate the tax liability in each of the $27 \mathrm{EU}$ member states the European Tax Analyzer accounts for all taxes that may be influenced by the investments and financing at the corporate level. Consequently, in addition to the corporate income tax, real estate taxes, payroll taxes, various types of trade taxes (e.g. on income, capital or value added), net wealth taxes as well as surcharges are considered. A detailed description of the tax parameters is given in the following Section 4 when the tax burdens of the member states are compared with each other.

The computation of the tax bases considers the most relevant assets and liabilities and the effects of the corporate planning. Furthermore, the tax module allows the selection of several accounting options (tax electives) enabling a company to influence its taxable profits. The following elements are considered for profit computation:

- Depreciation (methods and tax periods for all considered assets, extraordinary depreciation),

- Inventory (stock) valuation (production costs, FIFO, LIFO and the average costs method, inflation reserves),

- Research and Development costs (immediate expensing or capitalisation),

- Taxation of capital gains (roll-over relief, inflation adjustment, special tax rates),

- Employee pension schemes (deductibility of pension costs, contributions to pension funds, book reserves),

- Provisions for bad debts,

- Guarantee accruals,

- Elimination and mitigation of double taxation on foreign source income (exemption, foreign tax credit, deduction of foreign taxes), and

- Loss relief.

Finally, referring to tax rates, the calculations consider statutory linear as well as progressive structures. In the case of progressive rates - relevant for special provisions for small and medium-sized companies in some countries - the tax rates enter into the model as functions of the relevant income or net assets (non-profit taxes) according to the tax laws.

\subsection{Model-Firms, Data Base and Economic Assumptions}

This article considers two model firms: a large and a small and medium-sized company. Both were implemented into the model representing EU-27 average companies. An EU-27 average company is a model of a firm ignoring country and industry specific effects on pre-tax data meaning that balance sheet, profit and loss account and corporate planning of this model company are given and are not dependent on country-specific taxation rules. The data deter- 
mining the implemented model firms were mainly taken from the AMADEUS database and comprise balance sheet data as well as income statement data. ${ }^{8}$

The AMADEUS database provides financial and supplementary information for about 6.74 million companies in the EU. However, not all of them are included in the study. ${ }^{9}$ One reason is that the AMADEUS database also comprises companies of legal forms (e.g. partnerships) and of industries (e.g. mining) that are not relevant for the study. Furthermore, publicly owned companies are not addressed in the study, but covered by the AMADEUS database. Moreover, some companies have to be excluded because the minimum set of data required for the study is not available. Altogether, this reduces the number of companies used in the study to $1,147,483$ in total.

For the determination of the average model companies it had to be taken care that the structure of EU-average companies is not unduly influenced by a small number of member states or large companies. Therefore, it was decided to determine the items of the financial statements in relation to the "sales" or "total assets" for each company and to determine the average for the companies in each country. Consequently, the computation of the EU-average companies is based on country-specific average ratios for the balance sheet items and the income statement items. These country-specific ratios are subsequently aggregated to obtain the EU-average ratios. Finally, these ratios are multiplied with the average values for "sales" and "total assets" averaged out across the EU member states in order to produce the absolute values in Euros for the EU-average companies.

Table 1: Balance sheet of the implemented EU-27 model firms (period 6)

\begin{tabular}{|c|c|c|c|c|c|}
\hline Assets & $\begin{array}{l}\text { Small and me- } \\
\text { dium (in } € \text { ) }\end{array}$ & $\begin{array}{l}\text { Large } \\
\text { (in } € \text { ) }\end{array}$ & Liabilities & $\begin{array}{c}\text { Small and } \\
\text { medium (in } € \text { ) }\end{array}$ & $\begin{array}{l}\text { Large } \\
\text { (in } € \text { ) }\end{array}$ \\
\hline I. $\quad$ Fixed assets & $1,273,098$ & $49,641,583$ & 1. Shareholder funds & $1,254,419$ & $43,415,131$ \\
\hline $\begin{array}{l}\text { 1. Intangible fi- } \\
\text { xed assets }\end{array}$ & 74,800 & $2,875,872$ & 1. Capital & 420,924 & $18,207,742$ \\
\hline $\begin{array}{l}\text { 2. Tangible fixed } \\
\text { assets }\end{array}$ & $1,085,961$ & $37,793,443$ & $\begin{array}{l}\text { 2. Other shareholder } \\
\text { funds }\end{array}$ & 833,495 & $25,207,389$ \\
\hline \multirow{3}{*}{$\begin{array}{l}\text { 3. Other fixed as- } \\
\text { sets }\end{array}$} & 112,337 & $8,972,268$ & $\begin{array}{l}\text { 2. Non-current liabili- } \\
\text { ties }\end{array}$ & 747,802 & $27,433,693$ \\
\hline & & & 1. Long-term debt & 469,217 & $21,248,099$ \\
\hline & & & $\begin{array}{l}\text { 2. Other non-current } \\
\text { liabilities }\end{array}$ & 278,585 & $6,185,594$ \\
\hline II. Current assets & $2,985,322$ & $76,792,466$ & 3. Current liabilities & $2,256,199$ & $55,585,225$ \\
\hline 1. Stocks & 877,820 & $22,936,037$ & 1. Loans & 469,217 & $21,248,099$ \\
\hline 2. Debtors & $1,433,559$ & $15,945,781$ & 2. Creditors & 935,447 & $10,070,619$ \\
\hline $\begin{array}{l}\text { 3. Other current } \\
\text { assets }\end{array}$ & 673,943 & $37,910,648$ & $\begin{array}{l}\text { 3. Other current lia- } \\
\text { bilities }\end{array}$ & 851,535 & $24,266,507$ \\
\hline Total & $4,258,420$ & $126,434,049$ & Total & $4,258,420$ & $126,434,049$ \\
\hline
\end{tabular}

Table 1 shows the balance sheets of the generated model firms (i.e. SME and large corporations) at the end of year six (the mid-point of the ten year comparison). The balance sheets

\footnotetext{
${ }^{8}$ In addition to the AMADEUS database, EUROSTAT statistics, the BACH-Database and published company account data were complementary used to generate the average model companies.

${ }^{9}$ The determination of EU-average companies is based on update 125 as of February 2005 and refers to financial data for the year 2001. The main reason to choose year 2001 was that according to the Ifo Economic Climate Indicator for the Euro Area this year approximates the long-term average and thus represents balanced economic conditions.
} 
depict the different types of investments and their sources of finance. It also highlights the relative weight of these investments and the sources of finance. In addition, table 2 displays the most important financial ratios of both model firms.

Table 2: Financial ratios of the implemented EU-27 model firms (period 6)

\begin{tabular}{lrr}
\hline Financial Ratio & $\begin{array}{r}\text { Large EU-27 } \\
\text { average company }\end{array}$ & $\begin{array}{r}\text { Small and Medium-Sized EU-27 } \\
\text { average company }\end{array}$ \\
\hline Profit/loss for period & 4.124 .827 & 194.624 \\
\hline Total assets & 126.434 .049 & 4.258 .420 \\
\hline Sales & 159.457 .817 & 7.167 .799 \\
\hline $\begin{array}{l}\text { Share of tangible fixed } \\
\text { assets (=capital intensity) }\end{array}$ & $29.89 \%$ & $25.50 \%$ \\
\hline Return on sales & $2.59 \%$ & $2.72 \%$ \\
\hline Return on Equity & $9.50 \%$ & $15.52 \%$ \\
\hline Equity ratio & $34.34 \%$ & $29.46 \%$ \\
\hline Return on assets & $6.11 \%$ & $6.87 \%$ \\
\hline Inventories to capital & $18.14 \%$ & $20.61 \%$ \\
\hline $\begin{array}{l}\text { Costs for personnel to } \\
\text { turnover }\end{array}$ & & $18.20 \%$ \\
\hline
\end{tabular}

The calculations done for the model firms require several important economic assumptions which are defined as follows:

- Expected economic lifetime for depreciable assets: buildings (50 years); patents and concessions ( 5 years each); plant (4 years) and machinery (five assets are considered, 5 to 10 years); office furniture and fixtures (9 years).

- Rates of price increase: consumer price index (2.2\%); price index for basic material $(4.8 \%)$; price index for wages $(0.8 \%)$; price index for investment goods $(2.3 \%){ }^{10}$

- Interest rates for creditors and debtors: short term credit (3\%); long term credit $(3.9 \%)$; short term debt (5.9\%); long term debt $(5.1 \%) .{ }^{11}$

\section{Effective Company Tax Burdens in the EU Member States}

\subsection{Domestic Accounting}

To estimate the impact of common tax accounting rules, the effective tax burdens resulting from current domestic tax rules are examined first. The comparison takes into account the tax rules implemented as of the fiscal year 2006 in the 27 member states. Irrespective of the size of the corporation there is a remarkable dispersion of effective tax burdens across member states (see table 3). For the large corporation, tax burdens range from 13.86 Mio $€$ in Ireland to 55.17 Mio $€$ in France over the simulation period of 10 years. The average tax burden is 27.42 Mio $€$ and the standard deviation amounts to 9.41 Mio Euro. In case of a SME, tax burdens vary between 0.49 Mio $€$ in Ireland and 1.70 Mio $€$ in France; the EU average amounts to 0.96 Mio $€$ and the standard deviation to 0.32 Mio $€$. Both large and SME model firms bear a comparably low tax burden in those member states, which joined the EU recently. The tax burdens in Bulgaria, Cyprus, the Czech Republic, Estonia, Latvia, Lithuania, Poland, Roma-

\footnotetext{
${ }^{10}$ See ECB, 2006.

${ }^{11}$ See ECB, 2006; OECD, 2006.
} 
nia and Slovakia are significantly below EU average. Only Hungary, Malta and Slovenia display tax burdens above EU average. Ireland is the only country among the old member states which ranks on a top position.

Table 3: Comparison of corporate income tax rates and effective tax burdens (large company and SME, corporate level, year 2006)

\begin{tabular}{|c|c|c|c|c|c|c|c|}
\hline \multirow[b]{2}{*}{ Country } & \multirow{2}{*}{$\begin{array}{l}\text { Corporate In- } \\
\text { come Tax Rate } \\
\text { in } \%\end{array}$} & \multicolumn{3}{|c|}{ Large Company } & \multicolumn{3}{|c|}{ SME } \\
\hline & & $\begin{array}{c}\text { Tax Burden } \\
\text { in Mio } €\end{array}$ & Rank & $\begin{array}{c}\text { Deviation } \\
\text { from Average }\end{array}$ & $\begin{array}{c}\text { Tax Burden in } \\
\text { Mio } €\end{array}$ & Rank & $\begin{array}{c}\text { Deviation from } \\
\text { Average }\end{array}$ \\
\hline IE & 12.5 & 13.86 & 1 & $-49.5 \%$ & 0.49 & 1 & $-49.3 \%$ \\
\hline BG & 15.0 & 14.52 & 2 & $-47.1 \%$ & 0.52 & 2 & $-45.5 \%$ \\
\hline $\mathrm{EE}$ & 23.0 & 15.63 & 3 & $-43.0 \%$ & 0.55 & 3 & $-42.6 \%$ \\
\hline RO & 16.0 & 15.76 & 4 & $-42.5 \%$ & 0.56 & 4 & $-41.4 \%$ \\
\hline LV & 15.0 & 16.36 & 5 & $-40.3 \%$ & 0.58 & 5 & $-39.5 \%$ \\
\hline $\mathrm{CY}$ & 10.0 & 18.35 & 6 & $-33.1 \%$ & 0.67 & 6 & $-30.4 \%$ \\
\hline SK & 19.0 & 19.26 & 7 & $-29.7 \%$ & 0.69 & 7 & $-28.3 \%$ \\
\hline PL & 19.0 & 19.75 & 8 & $-27.9 \%$ & 0.71 & 8 & $-26.7 \%$ \\
\hline $\mathrm{LT}$ & 15.0 & 20.44 & 9 & $-25.4 \%$ & 0.73 & 9 & $-24.5 \%$ \\
\hline $\mathrm{CZ}$ & 24.0 & 23.38 & 10 & $-14.7 \%$ & 0.84 & 11 & $-12.6 \%$ \\
\hline FI & 26.0 & 26.23 & 11 & $-4.3 \%$ & 0.94 & 12 & $-2.6 \%$ \\
\hline PT & 25.0 & 26.72 & 12 & $-2.5 \%$ & 0.96 & 13 & $-0.2 \%$ \\
\hline SE & 28.0 & 27.19 & 13 & $-0.8 \%$ & 0.97 & 14 & $1.1 \%$ \\
\hline GR & 29.0 & 27.77 & 14 & $1.3 \%$ & 0.99 & 15 & $2.4 \%$ \\
\hline SL & 25.0 & 28.85 & 15 & $5.2 \%$ & 1.06 & 19 & $9.9 \%$ \\
\hline NL & $25.5-29.6$ & 28.94 & 16 & $5.6 \%$ & 1.02 & 16 & $6.2 \%$ \\
\hline LU & $20.0-22.0$ & 29.11 & 17 & $6.2 \%$ & 1.03 & 17 & $6.8 \%$ \\
\hline DK & 28.0 & 29.40 & 18 & $7.3 \%$ & 1.04 & 18 & $8.1 \%$ \\
\hline $\mathrm{BE}$ & $24.25-33.0$ & 31.43 & 19 & $14.6 \%$ & 1.13 & 20 & $17.4 \%$ \\
\hline UK & $19.0-30.0$ & 31.92 & 20 & $16.4 \%$ & 0.78 & 10 & $-19.1 \%$ \\
\hline AT & 25.0 & 33.05 & 21 & $20.6 \%$ & 1.21 & 22 & $25.8 \%$ \\
\hline MT & 35.0 & 33.63 & 22 & $22.7 \%$ & 1.21 & 21 & $25.3 \%$ \\
\hline ES & $30.0-35.0$ & 37.85 & 23 & $38.0 \%$ & 1.30 & 23 & $35.0 \%$ \\
\hline $\mathrm{HU}$ & 16.0 & 38.09 & 24 & $38.9 \%$ & 1.52 & 26 & $57.5 \%$ \\
\hline IT & 33.0 & 38.77 & 25 & $41.4 \%$ & 1.42 & 25 & $47.9 \%$ \\
\hline $\mathrm{DE}$ & 25.0 & 38.79 & 26 & $41.5 \%$ & 1.37 & 24 & $42.1 \%$ \\
\hline FR & $15.0-33.33$ & 55.17 & 27 & $101.2 \%$ & 1.70 & 27 & $77.0 \%$ \\
\hline EU-Ø & $23.79-25.61$ & 27.42 & & & 0.96 & & \\
\hline $\begin{array}{l}\text { Standard } \\
\text { Deviation }\end{array}$ & $8.7-8.9$ & 9.41 & & & 0.32 & & \\
\hline
\end{tabular}

The large member states France, Germany, Italy and Spain impose a relatively high tax burden on corporations. The effective tax burden in countries like the Czech Republic, Slovenia and continental countries like Greece, Luxembourg, the Netherlands, and Portugal as well as in the Scandinavian countries Finland and Sweden is closer to average. As a special case the United Kingdom can be identified where the progressive corporate income tax rate leads to a comparatively high tax burden for the large corporation and to a tax burden well below EU average for the SME.

The effective tax burden is influenced by different kinds of taxes (see table 4). ${ }^{12}$ In general, the corporate income tax constitutes the main share of the overall tax burden in all countries,

\footnotetext{
${ }^{12}$ The results of table 4 are based on calculations for a large corporation. As the tax weights are nearly unchanged for a SME it is refrained from presenting an additional table.
} 
except Hungary. Its share in the overall tax burden ranges from $41.25 \%$ in Hungary to $100 \%$ in Malta. This result shows that the corporate income tax rates shown in the second column of table 3 are a key driver for the identified average tax burdens.

Table 4: Impact of particular tax categories on the effective tax burden in \% (large company, year 2006)

\begin{tabular}{|c|c|c|c|c|c|c|}
\hline Country & $\begin{array}{c}\text { Real Estate } \\
\text { Tax }\end{array}$ & Payroll Tax & $\begin{array}{l}\text { Trade Tax on } \\
\text { Income }\end{array}$ & $\begin{array}{l}\text { Trade Tax on } \\
\text { Capital }\end{array}$ & $\begin{array}{l}\text { Net Wealth } \\
\text { Tax }\end{array}$ & $\begin{array}{l}\text { Corporate Tax } \\
\text { (+ Surcharges) }\end{array}$ \\
\hline AT & 4.75 & 23.25 & & & & 72.00 \\
\hline $\mathrm{BE}$ & 9.89 & & & & & 90.11 \\
\hline BG & 1.84 & & & & & 98.16 \\
\hline CY & 4.26 & 38.01 & & & & 57.73 \\
\hline $\mathrm{CZ}$ & 1.11 & & & & & 98.89 \\
\hline $\mathrm{DE}$ & 1.12 & & 34.19 & & & 64.69 \\
\hline DK & 9.03 & & & & & 90.97 \\
\hline $\mathrm{EE}$ & 5.80 & & & & & 94.20 \\
\hline ES & 1.23 & & & 12.04 & & 86.74 \\
\hline FI & 4.12 & & & & & 95.88 \\
\hline FR & 2.40 & 12.00 & & 26.58 & & 59.02 \\
\hline GR & 1.88 & & & & & 98.12 \\
\hline $\mathrm{HU}$ & 3.40 & & 55.35 & & & 41.25 \\
\hline IE & 9.52 & & & & & 90.48 \\
\hline IT & 1.62 & & 17.77 & & & 80.62 \\
\hline LT & 10.21 & & & & & 89.79 \\
\hline LU & 3.02 & & 20.90 & & 0.87 & 75.22 \\
\hline LV & 11.59 & & & & & 88.41 \\
\hline MT & 0 & & & & & 100.00 \\
\hline NL & 1.49 & & & & & 98.51 \\
\hline PL & 6.81 & & & & & 93.19 \\
\hline PT & 2.47 & & & & & 97.53 \\
\hline RO & 5.95 & & & & & 94.05 \\
\hline SE & 2.51 & & & & & 97.49 \\
\hline SK & 4.00 & & & & & 96.00 \\
\hline SL & 0 & 16.44 & & & & 83.56 \\
\hline UK & 9.76 & & & & & 90.24 \\
\hline
\end{tabular}

Besides corporate income tax, all countries, except Malta and Slovenia, levy real estate tax. The impact of real estate taxes on the overall tax burden is comparatively high in Belgium, Denmark, Ireland, Latvia, Lithuania, and in the United Kingdom. In these countries, the share of the real estate tax in the overall tax burden amounts to more than $9 \%$.

Additional taxes are levied in Austria, Cyprus, France, Germany, Hungary, Italy, Luxembourg, Spain and Slovenia. Germany, Luxembourg and Italy levy a trade tax on income. As real estate tax in Germany and Italy is negligible, the overall tax burden is above all determined by profit taxes, whereas the proportion of trade taxes is higher in Germany (Gewerbesteuer: $34.19 \%$ ) than in Italy (IRAP: 17.77\%). A different picture is given for Austria, Cyprus, France and Slovenia. Here, the overall tax burden is substantially determined by nonprofit taxes. All four countries impose a tax on payroll. Its share in the overall tax burden varies between $12.00 \%$ (France) and $38.01 \%$ (Cyprus). France also levies a trade tax on capital (taxe professionnelle), which amounts to $26.58 \%$ of the overall tax burden. 


\subsection{Case of a CCTB}

\subsubsection{Benchmark Case Reflecting an EU-27 Average Large and SME Corporation}

The changes of the effective tax burdens in the event of a CCTB for a large company and a SME are displayed in table 5. It is assumed that the rules outlined in Section 2 regarding depreciation, inventory valuation, determination of production costs, provisions for pensions, provisions for future liabilities, exemption of foreign dividend income and loss relief are implemented simultaneously.

Table 5: Changes in the effective tax burden in case of a common corporate tax base (large company and SME)

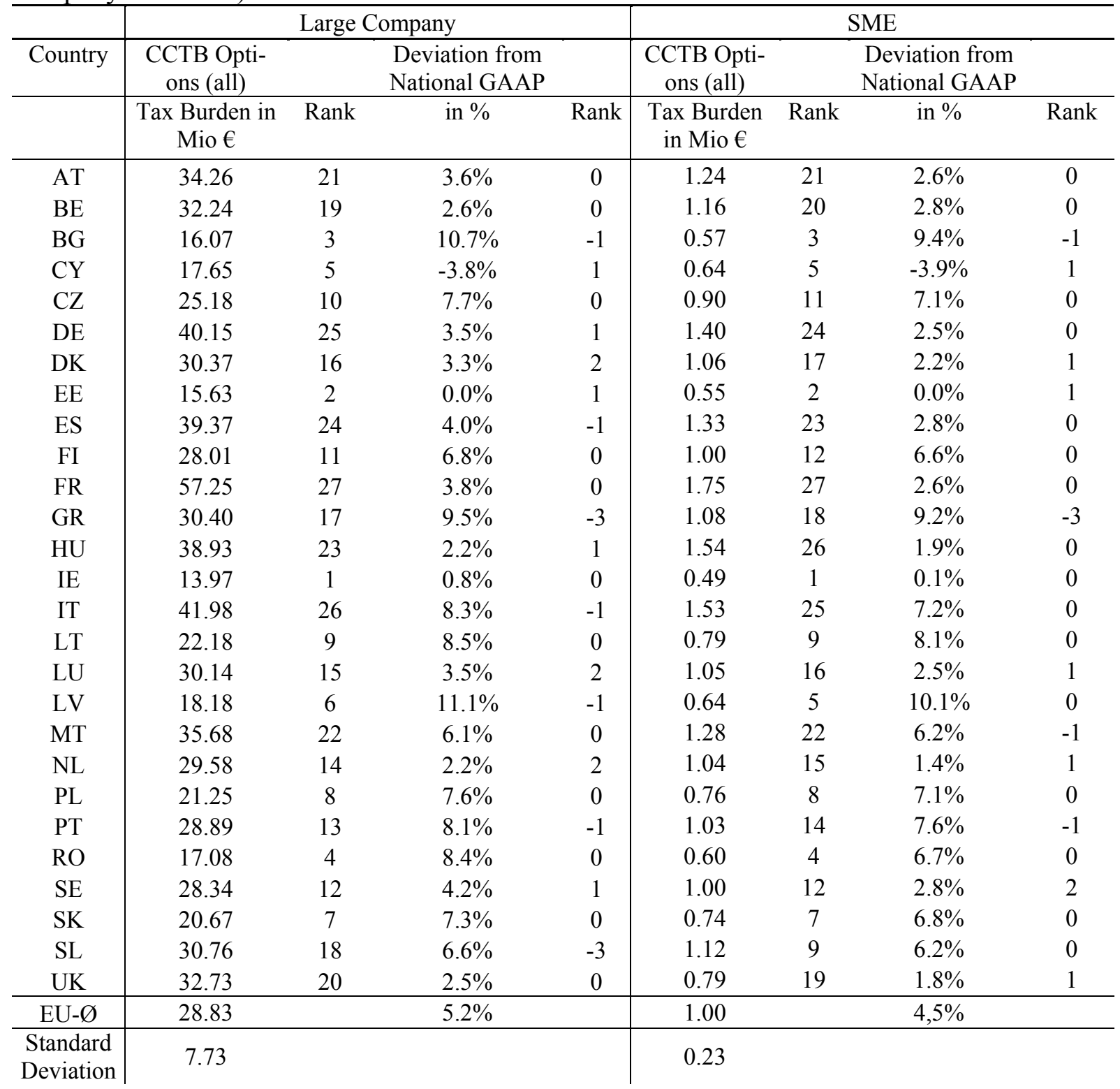

For a large company the effective tax burdens increase in all countries, except Cyprus and Estonia, if a CCTB is implemented. The increases range from $0.8 \%$ in Ireland to $11.1 \%$ in Latvia. On average, the effective tax burden increases by $5.2 \%$. After the harmonisation of the accounting rules, the effective tax burdens show a standard deviation of 7.73 Mio $€$. In Bulgaria, the Czech Republic, Finland, Greece, Italy, Latvia, Lithuania, Malta, Poland, Portugal, Romania, Slovakia and Slovenia the increase of the tax burden is above average. However, 
these changes rarely translate into a change in the ranking. 12 countries do not change positions. Cyprus, Denmark, Estonia, Germany, Hungary, Luxembourg, the Netherlands and Sweden improve their rank, but only between one and two positions. Bulgaria, Spain, Greece, Italy, Latvia, Portugal and Slovenia worsen their position in the ranking, but only between one and three positions.

In case of a SME the picture shows a similar pattern: in all countries, except Cyprus and Estonia, the introduction of a CCTB would result in a higher effective tax burden. The increases of the effective tax burdens range from $0.1 \%$ in Ireland to $10.1 \%$ in Latvia. On average, the effective tax burden increases by $4.5 \%$. For the SME effective tax burdens show a standard deviation of 0.23 Mio $€$. Bulgaria, the Czech Republic, Finland, Greece, Italy, Latvia, Lithuania, Malta, Poland, Portugal, Romania, Slovakia and Slovenia show an increase of the tax burden above average. However, 16 countries do not even change positions in the ranking. Cyprus, Denmark, Estonia, Luxembourg, the Netherlands, Sweden and the United Kingdom improve their rank, but only between one and two positions. Bulgaria, Greece, Malta and Portugal worsen their rank, but only between one and three positions.

Overall it can be stated that the introduction of a CCTB would lead to broader tax bases and, hence, to higher effective tax burdens. The development of the effective tax burden would introduce room for manoeuvre to reduce the nominal tax rates in order to keep the introduction of a CCTB revenue neutral. To what extent tax rate cuts seem to be possible cannot be quantified based on the identified average corporations and requires further research concerning microsimulation models assessing thousands of single corporations to be advanced. ${ }^{13}$

So far, the cumulative effects of common tax accounting rules on the effective tax burden have been analysed. In the following, the effects of the single elements of the CCTB (see section 2) are considered in isolation. Each simulation is based on a particular element of the tax base being harmonised across the EU while for all the other elements domestic accounting rules are still applied. This analysis helps to identify the effect and importance of specific elements of a CCTB. ${ }^{14}$ However, it has to be clarified that the changes caused by the isolated application of single CCTB options cannot be summed up to receive the cumulative effects of common tax accounting rules on the effective tax burden. The reasons for this result are timing effects caused by interdependencies between different CCTB options that can intensify or weaken the impact of changed tax rules on the size of the tax base. ${ }^{15}$ Table 6 displays the results which are discussed in the following.

\footnotetext{
${ }^{13}$ With the ZEW TaxCoMM a basic version of an adequate corporate microsimulation model was published recently. See Reister, Spengel, Finke, and Heckemeyer, 2008.

${ }^{14}$ In accordance with the determination of the tax weights the following calculations are based on the large model firm but hold also true for a SME.

${ }^{15}$ For example, changed depreciation rules lead to changed production costs when depreciation is included in the definition of the production costs. If the proposed CCTB options allow higher depreciation in comparison to domestic accounting but are more restrictive concerning the production cost definition the impact of changed depreciation rules on the size of the tax base is weakened in the case both options are regarded simultaneously.
} 
Table 6: Isolated impact of common rules of a CCTB on the effective tax burden in $\%$

\begin{tabular}{|c|c|c|c|c|c|c|c|c|c|c|}
\hline Country & National GAAP & Depreciation & $\begin{array}{l}\text { Valuation of } \\
\text { Inventories }\end{array}$ & $\begin{array}{l}\text { Production } \\
\text { Costs }\end{array}$ & $R \& D$ & $\begin{array}{l}\text { Pension } \\
\text { Scheme }\end{array}$ & $\begin{array}{l}\text { Warranty } \\
\text { Provisions }\end{array}$ & $\begin{array}{c}\text { Foreign } \\
\text { Dividends }\end{array}$ & $\begin{array}{l}\text { Treatment of } \\
\text { Losses }\end{array}$ & All Options \\
\hline & $\begin{array}{c}\text { Tax Burden in } \\
\text { Mio } €\end{array}$ & Deviation & Deviation & Deviation & Deviation & Deviation & Deviation & Deviation & Deviation & Deviation \\
\hline AT & 33.05 & $1.94 \%$ & $0.22 \%$ & $0.77 \%$ & $0.00 \%$ & $-0.59 \%$ & $0.00 \%$ & $0.00 \%$ & $0.00 \%$ & $3.65 \%$ \\
\hline BE & 31.43 & 0.19\% & $0.06 \%$ & $0.08 \%$ & $0.00 \%$ & $0.00 \%$ & $0.00 \%$ & $0.00 \%$ & $0.00 \%$ & $2.58 \%$ \\
\hline BG & 14.52 & $4.91 \%$ & $0.24 \%$ & $1.23 \%$ & $0.01 \%$ & $0.00 \%$ & $-1.33 \%$ & $0.00 \%$ & $0.00 \%$ & $10.70 \%$ \\
\hline CY & 18.35 & $0.40 \%$ & $0.00 \%$ & $-4.22 \%$ & $-0.27 \%$ & $0.00 \%$ & $-2.36 \%$ & $0.00 \%$ & $0.00 \%$ & $-3.82 \%$ \\
\hline CZ & 23.38 & $9.83 \%$ & $0.00 \%$ & $-0.01 \%$ & $0.01 \%$ & $0.00 \%$ & $-1.17 \%$ & $0.00 \%$ & $0.00 \%$ & $7.66 \%$ \\
\hline DE & 38.79 & $2.18 \%$ & $0.22 \%$ & $0.82 \%$ & $0.00 \%$ & $-0.65 \%$ & $0.00 \%$ & $0.00 \%$ & $0.00 \%$ & $3.49 \%$ \\
\hline DK & 29.40 & $1.24 \%$ & $-0.02 \%$ & $1.01 \%$ & $0.01 \%$ & $0.00 \%$ & $0.00 \%$ & $0.00 \%$ & $0.00 \%$ & $3.28 \%$ \\
\hline EE & 15.63 & $0.00 \%$ & $0.00 \%$ & $0.00 \%$ & $0.00 \%$ & $0.00 \%$ & $0.00 \%$ & $0.00 \%$ & $0.00 \%$ & $0.00 \%$ \\
\hline ES & 37.85 & $2.58 \%$ & $0.25 \%$ & $-0.07 \%$ & $-0.07 \%$ & $0.00 \%$ & $0.00 \%$ & $0.00 \%$ & $0.00 \%$ & $4.02 \%$ \\
\hline FI & 26.23 & $1.50 \%$ & $-0.02 \%$ & $1.09 \%$ & $0.01 \%$ & $0.00 \%$ & $-1.10 \%$ & $0.00 \%$ & $0.00 \%$ & $6.78 \%$ \\
\hline FR & 55.17 & $3.80 \%$ & $0.00 \%$ & $-0.01 \%$ & $0.01 \%$ & $0.00 \%$ & $0.00 \%$ & $0.00 \%$ & $0.00 \%$ & $3.77 \%$ \\
\hline GR & 27.77 & $4.49 \%$ & $0.00 \%$ & $0.60 \%$ & $0.01 \%$ & $0.00 \%$ & $-1.11 \%$ & $0.00 \%$ & $0.00 \%$ & $9.49 \%$ \\
\hline HU & 38.09 & $2.19 \%$ & $0.00 \%$ & $0.04 \%$ & $0.00 \%$ & $0.00 \%$ & $0.00 \%$ & $0.00 \%$ & $0.00 \%$ & $2.23 \%$ \\
\hline IE & 13.86 & $0.91 \%$ & $0.00 \%$ & $-0.01 \%$ & $0.01 \%$ & $0.00 \%$ & $0.00 \%$ & $0.00 \%$ & $0.00 \%$ & $0.81 \%$ \\
\hline IT & 38.77 & $6.60 \%$ & $0.97 \%$ & $-0.53 \%$ & $0.00 \%$ & $0.00 \%$ & $-1.70 \%$ & $0.00 \%$ & $0.00 \%$ & $8.27 \%$ \\
\hline LT & 20.44 & $10.33 \%$ & $-0.02 \%$ & $-0.01 \%$ & $0.01 \%$ & $0.00 \%$ & $-1.13 \%$ & $0.00 \%$ & $0.00 \%$ & $8.50 \%$ \\
\hline $\mathbf{L U}$ & 29.11 & $2.52 \%$ & $0.36 \%$ & $-0.40 \%$ & $-0.09 \%$ & $0.00 \%$ & $0.00 \%$ & $0.00 \%$ & $0.00 \%$ & $3.55 \%$ \\
\hline LV & 16.36 & $13.06 \%$ & $0.00 \%$ & $0.00 \%$ & $0.00 \%$ & $0.00 \%$ & $0.00 \%$ & $0.00 \%$ & $0.00 \%$ & $11.15 \%$ \\
\hline MT & 33.63 & $1.54 \%$ & $0.00 \%$ & $0.90 \%$ & $-0.09 \%$ & $0.00 \%$ & $-1.00 \%$ & $-0.35 \%$ & $0.00 \%$ & $6.11 \%$ \\
\hline NL & 28.94 & $1.67 \%$ & $0.40 \%$ & $0.00 \%$ & $0.00 \%$ & $-0.40 \%$ & $0.00 \%$ & $0.00 \%$ & $0.00 \%$ & $2.20 \%$ \\
\hline PL & 19.75 & $5.80 \%$ & $0.31 \%$ & $-0.01 \%$ & $0.01 \%$ & $0.00 \%$ & $-1.17 \%$ & $0.00 \%$ & $0.00 \%$ & $7.57 \%$ \\
\hline PT & 26.72 & $3.00 \%$ & $0.22 \%$ & $0.41 \%$ & $0.01 \%$ & $0.00 \%$ & $-1.12 \%$ & $0.00 \%$ & $0.00 \%$ & $8.11 \%$ \\
\hline RO & 15.76 & $6.65 \%$ & $0.25 \%$ & $1.46 \%$ & $0.00 \%$ & $0.00 \%$ & $0.00 \%$ & $0.00 \%$ & $0.00 \%$ & $8.38 \%$ \\
\hline SE & 27.19 & $4.64 \%$ & $0.00 \%$ & $-0.08 \%$ & $-0.08 \%$ & $0.00 \%$ & $0.00 \%$ & $0.00 \%$ & $0.00 \%$ & $4.21 \%$ \\
\hline SK & 19.26 & $9.34 \%$ & $0.00 \%$ & $-0.01 \%$ & $0.01 \%$ & $0.00 \%$ & $-1.20 \%$ & $0.00 \%$ & $0.00 \%$ & $7.27 \%$ \\
\hline SL & 28.85 & $1.45 \%$ & $0.29 \%$ & $0.88 \%$ & $0.00 \%$ & $0.00 \%$ & $-0.97 \%$ & $0.00 \%$ & $0.00 \%$ & $6.63 \%$ \\
\hline UK & 31.92 & $2.62 \%$ & $0.00 \%$ & $-0.02 \%$ & $0.01 \%$ & $0.00 \%$ & $0.00 \%$ & $-0.01 \%$ & $0.00 \%$ & $2.51 \%$ \\
\hline EU-Ø & 27.42 & $3.90 \%$ & $0.14 \%$ & $0.15 \%$ & $-0.02 \%$ & $-0.06 \%$ & $-0.57 \%$ & $-0.01 \%$ & $0.00 \%$ & $5.15 \%$ \\
\hline
\end{tabular}

\section{(1) Isolated harmonisation of rules governing tax depreciation}

Depreciation is a core element in determining the size of the tax base. Deviations between current domestic depreciation rules and common depreciation rules are caused by different depreciation methods and rates. Tax depreciation rules following Option A lead to a broadening of the tax base and thus, to a higher effective tax burden in all member states. Increases range from 0.19\% in Belgium to 13.06\% in Latvia (see Table 6, Column 3).

The highest increases of the tax burdens are calculated for the Czech Republic, Latvia, Lithuania and Slovakia. Thus, the current depreciation rules in these countries according to national tax law can be deemed comparably generous because the introduction of CCTB depreciation rules leads to a significant increase of the tax burden. In contrast, the current tax depreciation rules in Belgium, Cyprus, Finland, Denmark, Ireland, Malta, the Netherlands and Slovenia are rather restrictive. In these countries, the effective tax burden would increase only by $1.67 \%$ at the maximum, if common tax depreciation rules were introduced.

Overall, the impact of common tax depreciation rules is of very high relevance when it comes to effects on the effective tax burden. On average, the effective tax burden increases by $3.9 \%$. In relation to an overall effect amounting to $5.2 \%$ in the event of a CCTB, depreciation can be classified as the option with the definitely most important impact on the tax base. Breaking the overall effect down on the impact of depreciation provisions for specific categories of assets, there is a pre-eminent impact of common depreciation rules for machinery and equipment which clearly dominates the effects based on the depreciation for buildings and intangibles.

(2) Isolated harmonisation of methods for simplified valuation of inventories on the effective tax burden

The weighted average costs method (WAC) was chosen as an option for the CCTB. Accordingly, items in inventory and the cost of goods which are sold are valued with the average 
costs of the units being in stock at that time. Given inflation and rising costs over time, as it is assumed for these calculations, inventory is valued comparably moderate at average costs. Changes of the effective tax burdens resulting from the introduction of the WAC-method are displayed in table 6 , column 4 .

Compared to the LIFO-method which is used in most member states' national tax laws the WAC-method results in a higher tax burden. Austria, Italy, Luxembourg, the Netherlands, Poland and Slovenia show the highest increase of the effective tax burden when WAC is applied. Compared to countries applying the FIFO-method in their national tax law (e.g. Denmark, Finland and Lithuania), the tax burden with WAC is reduced. Consistently, there is no change for countries which already apply the WAC method in their national tax law.

Overall, the impact of the WAC-method on the effective tax burden ranges from $-0.02 \%$ in Lithuania to $0.97 \%$ in Italy. Most countries show an increase of less than $0.25 \%$, the EU-wide average increase amounts to $0.14 \%$. Consequently, the method used for the assessment of inventory has only a moderate impact on the effective tax burden.

\section{(3) Effect of common rules for the determination of production costs}

Depending on the rules for the determination of production costs, expenses are either deductible for accounting and taxation purposes in the period in which they occur or in which they are capitalised. If the costs are capitalised, they increase the value of the stock of inventory and their tax deduction is thus deferred to the period in which the specific asset is sold. As for the previous options for a CCTB, the tax base is only affected by timing effects. Here, in addition to direct costs indirect costs which are associated with the production process and which can be allocated to individual assets have to be included in production costs. The results show that the effective tax burden would change only moderately in most countries (see Table 6, Column 5).

The effective tax burden in the Czech Republic, France, Ireland, Latvia, Lithuania, the Netherlands, Poland, Slovakia and the United Kingdom do not change at all or only to a very small extent. This indicates that the current tax practice in these countries is already in line with the respective CCTB option. Increases are presented for Austria, Belgium, Bulgaria, Denmark, Estonia, Finland, Germany, Greece, Malta, Portugal, Romania and Slovenia. In these countries' current tax practice, not all of the costs related to the production of assets are included in the production costs. In contrast, the effective tax burden decreases in Cyprus, Hungary, Luxembourg, Spain, Sweden and Italy. The main reason is that most of these countries demand research and development costs to be capitalised. For the purposes of a CCTB, however, production costs include only those research and development costs which are deemed to be closely related to the production process. Thus, production costs according to the current tax law in these countries are higher compared to the production costs under a CCTB.

Altogether, the impact of the determination of production costs on the effective tax burden with an overall EU-average increase of $0.15 \%$ is comparable to option B. But it may not be ignored that the country-specific impact of the production costs on the effective tax burden ranges from $-4.22 \%$ in Cyprus to $1.46 \%$ in Romania..

\section{(4) Effect of common rules for the capitalization of $R \& D$ costs within production costs}

The CCTB considers an inclusion of $\mathrm{R} \& \mathrm{D}$ costs into production costs when these costs are related closely to production. Therefore, $R \& D$ costs related to production are included into 
production costs and reduce the tax base when the underlying goods are sold. The results of the simulation reveal that there is no considerable impact of $\mathrm{R} \& \mathrm{D}$ costs related to production on the effective tax burden (see Table 6, Column 6). According to domestic tax law, some countries demand to include almost all R\&D costs into production costs even if they are not closely related to production such as (basic) research or generic development. Their tax base decreases when $R \& D$ costs are included only with the production related part in production costs, since a higher portion of $R \& D$ expenditure is tax effective in earlier periods. These countries show lower effective tax burdens. Cyprus (-0.27\%), Spain (-0.07\%), Luxemburg ($0.09 \%)$, Malta $(-0.08 \%)$ and Sweden $(-0.08 \%)$ are affected in this way. All other countries experience no change (countries in which the national GAAP rule and the CCTB option are the same, for example Austria, Belgium and Germany) or only a very little positive change (countries which allow an expensing of all R\&D costs, for example Bulgaria, France and the United Kingdom) of the effective tax burden. On EU-average there is an overall decrease in the effective tax burden of only $-0.02 \%$.

\section{(5) Effect of common rules regarding provisions for pensions}

The simulations indicate that common tax accounting rules concerning pensions based on IFRS, which is the underlying assumption of Option E, is in line with tax practice in most countries. Hence, this option would result in an identifiable change of the effective tax burden only in Austria (-0.59\%), Germany (-0.65\%) and the Netherlands $(-0.40 \%)$ (see Table 6, Column 7). In these three countries, common tax accounting rules in the field of pension provisions would lead to a reduction of the effective tax burden.

This result stems mainly from different discount rates. Austria and Germany require a discount rate of $6 \%$, in the Netherlands it is fixed at $4 \%$. In contrast, the CCTB provisions assume a discount rate of $3 \%$ which corresponds with the short term credit interest rate. Overall, driven by the changes in the three countries mentioned the introduction of common rules for the determination of pension liabilities results on EU average in a decrease of the effective tax burden of $-0.06 \%$.

\section{(6) Effect of provisions for future warranty liabilities}

Future uncertain but probable liabilities arise out of legal requirements for product warranties. There are basically two possibilities to account for these liabilities. The considered CCTB option here is to treat contributions to such accruals as tax deductible. The other option is to disable the tax deduction of those contributions. About half of the member states treat the contributions as tax deductible. In that case costs can be recognised on an accruals basis before they have to be paid and they lower the taxable base before the liability is effectively due to pay. This practice leads to earlier tax effective deductions. Due to the described timing advantages, accruals for future liabilities therefore result in a lower effective tax burden.

Countries allowing no tax effective provision for warranty payments according to national tax law, in contrast, tighten the tax base when the CCTB is applied (see Table 6, Column 8). The maximum reduction is considered in Cyprus (-2.36\%). But also other countries like Bulgaria, Italy and Slovakia show a significant decrease of the effective tax burden. Overall, on EUaverage the introduction of common rules for accounting for provisions for future warranty liabilities results in a considerable decrease of the effective tax burden of $-0.57 \%$.

(7) Avoidance of double taxation of dividend income by applying the exemption method for dividend income from major shareholdings 
According to present tax law, Greece, Ireland, Malta, Poland and the United Kingdom grant a limited tax credit for dividends from major shareholdings. The CCTB proposes to exempt dividends from major shareholdings (participation ratio $\geq 10 \%$ of shares). Compared to the credit method, exemption of foreign dividends results in a lower periodical tax base because dividends are excluded from taxation. But as far as the effective tax burden is concerned both methods lead to the same result if the initial statutory tax rate abroad is above the tax rate of the home country of the corporation. For the underlying calculations an initial level of dividend tax burden of $30 \%$ is assumed. Consequently, the CCTB only lowers the effective tax burden in Malta (see Table 6, Column 9), where the national corporate income tax rate amounts to $35 \%{ }^{16}$

\section{(8) Effect of unlimited loss carry forward}

The large model firm considered in the base case scenario is a profitable company and shows no losses from regular activities during the simulation period of 10 years. The isolated application of the CCTB proposing an indefinite loss carry forward itself does, therefore, not result in changes of the tax burden of the model firm.

\subsubsection{Sensitivity Analysis on Specific Sectors}

The findings presented in section 4.2.1 are relevant for EU-average companies. The results could be different for companies revealing different economic structures. To enlarge the spectrum of the analysis in the following large companies belonging to different sectors are analysed in isolation. The four different sectors considered are: construction, commerce, energy and manufacturing. The data determining the implemented model firms were again mainly taken from the AMADEUS database. The companies representing these sectors are characterized by a specific set of financial ratios shown in table 7 .

Table 7: Financial ratios of sector-specific companies (large company, period 6)

\begin{tabular}{|c|c|c|c|c|c|}
\hline Financial Ratio & Benchmark Case & Commerce & Construction & Energy & Manufacturing \\
\hline Profit/loss for period & 4.124 .827 & 4.100 .087 & 2.589 .102 & 14038918 & 5.087 .719 \\
\hline Total assets & 126.434 .049 & 106.491 .860 & 92.198 .048 & 507.777 .252 & 158.673 .640 \\
\hline Sales & 159.457 .817 & 235.488 .844 & 100.372 .294 & 296.484 .315 & 169.088 .711 \\
\hline $\begin{array}{l}\text { Share of tangible fixed } \\
\text { assets (=capital intensity) }\end{array}$ & $29.89 \%$ & $22.37 \%$ & $19.03 \%$ & $42.85 \%$ & $33.66 \%$ \\
\hline Return on sales & $2.59 \%$ & $1.74 \%$ & $2.58 \%$ & $4.74 \%$ & $3.01 \%$ \\
\hline Return on Equity & $9.50 \%$ & $13.75 \%$ & $9.88 \%$ & $6.60 \%$ & $8.07 \%$ \\
\hline Equity ratio & $34.34 \%$ & $28.00 \%$ & $28.44 \%$ & $41.87 \%$ & $39.75 \%$ \\
\hline Return on assets & $6.11 \%$ & $6.13 \%$ & $4.65 \%$ & $5.50 \%$ & $5.91 \%$ \\
\hline Inventories to capital & $18.14 \%$ & $26.66 \%$ & $18.11 \%$ & $5.10 \%$ & $19.20 \%$ \\
\hline $\begin{array}{l}\text { Costs for personnel to } \\
\text { turnover }\end{array}$ & $20.97 \%$ & $11.76 \%$ & $22.78 \%$ & $11.51 \%$ & $20.93 \%$ \\
\hline
\end{tabular}

\footnotetext{
${ }^{16}$ In case of a lower initial level of dividend tax burden this option could also become relevant for other tax credit countries and lead to further decreases in effective tax burdens. On the contrary results for countries which already exempt dividends would stay stable.
} 
For the considered sector-specific companies the effective tax burdens under national GAAP as well as the deviation caused by the introduction of a CCTB are displayed in table 8 .

Table 8: Effective tax burden under national GAAP (in Mio $€$ ) and deviation caused by CCTB for different sectors (large company)

\begin{tabular}{|c|c|c|c|c|c|c|c|c|}
\hline \multirow[t]{2}{*}{ Country } & \multicolumn{2}{|c|}{ Commerce } & \multicolumn{2}{|c|}{ Construction } & \multicolumn{2}{|c|}{ Energy } & \multicolumn{2}{|c|}{ Manufacturing } \\
\hline & Nat. GAAP & Deviation & Nat. GAAP & Deviation & Nat. GAAP & Deviation & Nat. GAAP & Deviation \\
\hline $\mathrm{AT}$ & 30.17 & $2.2 \%$ & 20.46 & $2.9 \%$ & 84.03 & $7.4 \%$ & 41.91 & $4.8 \%$ \\
\hline $\mathrm{BE}$ & 30.55 & $0.3 \%$ & 18.51 & $1.3 \%$ & 89.71 & $8.8 \%$ & 40.88 & $4.2 \%$ \\
\hline BG & 13.95 & $7.7 \%$ & 8.87 & $9.8 \%$ & 38.92 & $16.2 \%$ & 19.18 & $11.6 \%$ \\
\hline $\mathrm{CY}$ & 16.28 & $-3.2 \%$ & 11.54 & $-4.2 \%$ & 42.55 & $-2.3 \%$ & 22.72 & $-3.9 \%$ \\
\hline $\mathrm{CZ}$ & 22.49 & $4.9 \%$ & 14.40 & $6.3 \%$ & 62.27 & $12.3 \%$ & 30.94 & $8.3 \%$ \\
\hline $\mathrm{DE}$ & 36.20 & $2.3 \%$ & 24.03 & $2.7 \%$ & 109.02 & $7.2 \%$ & 52.38 & $5.3 \%$ \\
\hline DK & 27.38 & $2.1 \%$ & 17.35 & $2.3 \%$ & 94.23 & $6.0 \%$ & 39.35 & $4.3 \%$ \\
\hline $\mathrm{EE}$ & 13.45 & $0.0 \%$ & 9.78 & $0.0 \%$ & 37.75 & $0.0 \%$ & 21.87 & $0.0 \%$ \\
\hline ES & 36.06 & $1.8 \%$ & 23.23 & $2.8 \%$ & 101.69 & $9.6 \%$ & 50.19 & $6.2 \%$ \\
\hline FI & 24.79 & $5.4 \%$ & 15.86 & $5.8 \%$ & 75.49 & $9.5 \%$ & 34.82 & $7.4 \%$ \\
\hline FR & 61.89 & $1.8 \%$ & 34.11 & $3.0 \%$ & 142.64 & $6.7 \%$ & 68.14 & $5.6 \%$ \\
\hline GR & 26.68 & $6.7 \%$ & 16.99 & $8.5 \%$ & 74.64 & $14.5 \%$ & 36.74 & $10.3 \%$ \\
\hline $\mathrm{HU}$ & 51.85 & $0.6 \%$ & 22.82 & $1.6 \%$ & 85.63 & $3.4 \%$ & 45.74 & $2.5 \%$ \\
\hline IE & 12.85 & $0.1 \%$ & 8.16 & $0.1 \%$ & 45.45 & $2.1 \%$ & 18.55 & $1.8 \%$ \\
\hline IT & 37.47 & $5.9 \%$ & 23.75 & $7.4 \%$ & 101.33 & $12.0 \%$ & 50.26 & $9.8 \%$ \\
\hline $\mathrm{LT}$ & 19.31 & $5.8 \%$ & 12.10 & $6.8 \%$ & 64.52 & $13.6 \%$ & 27.27 & $9.2 \%$ \\
\hline LU & 27.51 & $1.8 \%$ & 17.70 & $2.5 \%$ & 81.44 & $8.3 \%$ & 38.80 & $4.7 \%$ \\
\hline $\mathrm{LV}$ & 15.50 & $7.7 \%$ & 9.59 & $8.7 \%$ & 51.53 & $23.5 \%$ & 21.81 & $12.2 \%$ \\
\hline MT & 31.96 & $4.9 \%$ & 20.73 & $5.2 \%$ & 88.48 & $9.5 \%$ & 44.56 & $6.9 \%$ \\
\hline $\mathrm{NL}$ & 27.34 & $1.0 \%$ & 17.73 & $1.2 \%$ & 78.41 & $7.2 \%$ & 38.38 & $3.5 \%$ \\
\hline PL & 18.76 & $5.2 \%$ & 11.81 & $6.6 \%$ & 58.51 & $12.6 \%$ & 26.26 & $8.2 \%$ \\
\hline $\mathrm{PT}$ & 25.50 & $6.1 \%$ & 16.27 & $7.6 \%$ & 73.94 & $10.1 \%$ & 35.35 & $8.8 \%$ \\
\hline RO & 15.48 & $2.8 \%$ & 9.66 & $5.9 \%$ & 47.24 & $10.7 \%$ & 21.06 & $9.0 \%$ \\
\hline SE & 25.92 & $1.9 \%$ & 16.60 & $3.0 \%$ & 74.82 & $9.8 \%$ & 36.07 & $5.6 \%$ \\
\hline SK & 18.38 & $4.8 \%$ & 11.72 & $5.8 \%$ & 54.20 & $12.2 \%$ & 25.55 & $7.9 \%$ \\
\hline SL & 26.86 & $5.5 \%$ & 18.11 & $5.8 \%$ & 68.29 & $10.2 \%$ & 36.90 & $7.3 \%$ \\
\hline UK & 29.85 & $0.8 \%$ & 18.79 & $1.4 \%$ & 103.03 & $5.9 \%$ & 42.69 & $3.7 \%$ \\
\hline EU-Ø & 26.83 & $3.2 \%$ & 16.69 & $4.1 \%$ & 75.18 & $9.2 \%$ & 35.87 & $6.1 \%$ \\
\hline $\begin{array}{l}\text { Standard } \\
\text { Deviation }\end{array}$ & 11.32 & & 5.93 & & 24.73 & & 11.93 & \\
\hline
\end{tabular}

Focussing on the commerce sector the effective tax burden is on average lower than for the benchmark case ( 26.83 vs. 27.42 , see tables 8 and 3 ). On average, the increase in the commerce sector amounts to $3.2 \%$ compared to $5.2 \%$ in the benchmark case. The differences are caused by the specific financial ratios that are characteristic for both companies (see table 7). On the one hand the main reason for lower effective tax burdens is a slightly lower profit in the commerce sector. On the other hand the weakened impact of a CCTB is primarily caused by comparably lower capital intensity in the commerce sector. Lower capital intensity means that depreciation rules become less important since the proportion of depreciable tangible assets in total assets decreases. As depreciation rules are the key driver for deviations between national GAAP and CCTB (see section 4.2.1) the EU-average deviation for the commerce sector decreases significantly. 
As indicated in table 7 the model firm representing the construction sector shows lower annual profits than the benchmark case as well. Consequently, the effective tax burden is again below the one of the company of the benchmark case when national GAAP is applied (16.69 vs. 27.42. see tables 8 and 3). The same holds true for capital intensity which is also lower for the construction sector and, therefore, lowers the impact of a CCTB introduction to $4.1 \%$. However, this decline is not that strong as in the commerce sector. The main reason for this effect is a technical one. As the effective tax burden is comparably low in the construction sector the same absolute changes in the effective tax burden lead to stronger relative changes.

In case of the energy sector the identified effects concerning profitability and capital intensity affect the effective tax burden and the deviation between national GAAP and CCTB in the opposite direction. Compared to the benchmark case, the manufacturing sector yields evidently higher annual profits (see table 7) leading to a higher effective tax burden (75.18 vs. 27.42, see tables 8 and 3). As the capital intensity of the manufacturing sector exceeds the share of tangible fixed assets in the benchmark case, the introduction of a CCTB leads to a comparatively strong EU-average deviation between national GAAP and CCTB (9.2\%).

The average company of the manufacturing sector yields higher profits than the benchmark company but lower profits than the energy company (see table 7). Consequently, the effective tax burden under national GAAP (35.87) ranges between the two other scenarios (see tables 8 and 3). An analogue result occurs for the deviations between national GAAP and CCTB. Since the capital intensity in the manufacturing sector is higher than in the benchmark case but lower than in the energy sector the average deviation of $6.1 \%$ shown in table 7 oscillates between the benchmark case and the energy sector.

Irrespective of the sector type the introduction of a CCTB would in general result in broader tax bases and, therefore, in higher effective tax burdens. Consequently, the findings worked out for the benchmark case are confirmed by the sector-specific analysis: against the background of revenue neutrality the introduction of a CCTB can be combined with a reduction of nominal tax rates.

\section{Conclusion}

The European Commission is working on proposals for a tax reform that would allow improving the efficiency and simplicity of the corporate income tax systems in the EU. One policy option discussed is the introduction of a Common Corporate Tax Base (CCTB). This option would replace the current 27 tax codes for the calculation of taxable income across EU member states by a single and common set of tax rules.

The CCTB concept considered here comprises concrete taxation rules for eight different elements of the tax base: depreciation rules, valuation of inventories, determination of production costs, treatment of $\mathrm{R} \& \mathrm{D}$ costs, provisions for future pension payments, provisions for legal obligations, avoidance of double taxation of dividend income and loss relief.

Quantitative analyses for EU-27 average large and small and medium-sized companies show remarkable dispersions of effective tax burdens across member states. Furthermore, the proposed CCTB has a considerable impact on the effective tax burdens in the EU member states. In general, the CCTB would broaden the tax bases within the EU. Consequently, except for Cyprus, the effective tax burdens would increase in all countries if all member states uni- 
formly adopt a CCTB. Behind the background of revenue neutrality of an introduction of a CCTB these results indicate that a reduction of nominal tax rates within in EU member states would be possible.

The higher effective tax burdens in case of a CCTB are mainly driven by proposed restrictive depreciation rules. However, the development of the effective tax burdens strongly depends on the economic structure of the companies. Separate analyses for sector-specific companies revealed that there is a considerable variation in the consequences of CCTB. In this context, firm-specific capital intensity turned out to be the most relevant factor since a low capital intensity can be used as an indicator for a minor importance of depreciation rules. 


\section{References}

Common Consolidated Corporate Tax Base Working Group (2007), CCCTB: possible elements of a technical outline, CCCTB/WP057\doclen, Brussels.

Devereux, M.P. and R. Griffith (1999), The Taxation of Discrete Investment Choices - Revision 2, The Institute for Fiscal Studies, Working Paper Series No. W98/16, London.

Devereux, M.P. and R. Griffith (1998), Taxes and the Location of Production: Evidence from a Panel of US Multinationals, Journal of Public Economic, 335-367.

ECB (2006), ECB and Eurostat calculations, Frankfurt am Main.

ECB (2006), MFI interest rate statistics, December 2006, Frankfurt am Main.

Gutekunst, G. (2005), Steuerbelastungen und Steuerwirkungen bei nationaler und grenzüberschreitender Geschäftstätigkeit, Lohmar.

Jacobs, O.H. and C. Spengel (1996), European Tax Analyzer: EDV gestützter Vergleich der Steuerbelastung von Kapitalgesellschaften in Deutschland, Frankreich und Großbritannien, Baden-Baden.

Jacobs, O.H. and C. Spengel (2000), Measurement and Development of the Effective Tax Burden of Companies - An Overview and International Comparison, Intertax, 334351 .

Jacobs, O.H. and C. Spengel (2002), Effective Tax Burden of Companies in Europe - Current Situation, Past Developments and Simulation of Reforms, ZEW Economic Studies 15, Heidelberg.

Meyer, R. (1996), Computergestützte Simulation von Steuerbelastungen, Baden-Baden.

OECD (2006), Financial indicators MEI, Paris.

Reister, T., C. Spengel, K. Finke, and J. Heckemeyer (2008), ZEW Corporate Taxation Microsimulation Model (ZEW Tax CoMM), ZEW Discussion Paper No. 08-117, Mannheim.

Richter, W.F., H. Seitz., and W. Wiegard (1996), Steuern und unternehmensbezogene Staatsausgaben als Standortfaktoren, in: Siebert, H. (Ed.), Standortpolitik und Standortqualität, Tübingen, 13-47.

Schreiber, U., C. Spengel, and L. Lammersen (2002), Measuring the Impact of Taxation on Investment and Financial Decisions, Schmalenbach business review, 2-23.

Spengel, C. (1995), Europäische Steuerbelastungsvergleiche: Deutschland - Frankreich Großbritannien, Düsseldorf. 
Stetter, T. (2005), Computergestützte internationale Steuerbelastungsvergleiche. Bausteinbasiertes Metamodell zur Modellierung von Steuersystemen, Lohmar. 